\title{
HUMAN RESOURCE MANAGEMENT-RESEARCH PERFORMANCE LINKAGE IN HIGHER EDUCATION INSTITUTIONS
}

\author{
Jolanta Jaškienè \\ Ilona Buciuniene ${ }^{* *}$
}

Received: 11. 9. 2020

Review

Accepted: 23. 2. 2021

UDC 005.96:37

DOI https://doi.org/10.30924/mjcmi.26.1.9

\begin{abstract}
Research performance enhancement has become a greater issue in recent decades. However, studies analyzing the determinants of research performance and identifying human resource management (HRM) practices that improve research performance have been few and inconsistent. This paper overviews the factors affecting research performance and responds to calls for HRM practices that are customized for research and higher education institutions (HEIs). The paper is based on a theoretical HRM-performance linkage and
\end{abstract}

Abstract

\section{INTRODUCTION}

Research performance management and the ranking of higher education institutions (HEIs) or faculty members based on research performance have been important issues in the past two decades, and the antecedents of research performance have been examined by several scholars covering various research areas and institutions (Fox \& Mohapatra, 2007; Valle \& Schultz, 2011; White et al., 2012; Kiewra \& Creswell, 2000; Teodorescu, 2000). aims to identify research performance measures, define scholars' skills, abilities, research-oriented attitudes, and behaviors related to research performance, and generate bundles of abilities, motivation, and opportunities enhancing HRM practices associated with research performance. Finally, a theoretical framework for the HRM-research performance chain is developed.

Keywords: HRM practices, HRMperformance linkage, research performance, higher education institutions

More and more studies on HEI topics have shown that the enhancement of research performance has become one of the most important challenges for European HEIs (Smeby \& Try, 2005). However, Europe still lags behind the USA in the production of highly cited research (Rodriguez-Navarro \& Narin, 2018). Furthermore, universities with more intensive management have greater research productivity and faster growth (Beerkens, 2013). Therefore, the questions "How can

\footnotetext{
Jolanta Jaškienè (corresponding author), ISM University of Management and Economics, Arkliu str. 18, Vilnius, LT-01305, Lithuania, Phone: +370 687 23237, E-mail: jolanta.jaskiene@ism.lt, ORCID: https://orcid.org/00000002-0351-6059

** Ilona Buciuniene, ISM University of Management and Economics, Arkliu str. 18, Vilnius, LT-01305, Lithuania, Phone:+370 612 59673, E-mail: ilona.buciuniene@ism.lt, ORCID: https://orcid.org/0000-0002-5773-8693
} 


\section{Journal of Contemporary Management Issues}

research performance be stimulated?" and "How does HRM enhance research performance?" are of great importance.

Strategic HRM scholars have been encouraged to dedicate attention to the HRM practices applied within the industry, "by focusing on a single industry, the researcher is better able to ... identify strategic issues that influence the management of human resources" (Delery, 1998, p. 306). Moreover, the effectiveness of HRM systems depends on the contextual factors (Datta et al., 2005); thus unfolding the context of a specific industry and developing HR configuration to achieve required performance are necessary for HRM efficacy (Boxall \& Steeneveld, 1999; Boxall et al., 2019). While a considerable amount of research has been dedicated to the HRM-performance linkage in manufacturing, service, and other industries, few studies have analyzed HRM as the determinant of research performance in HEIs.

Explanations of research performance have varied across studies and were: dedicated to a single element stimulating research performance (De Stefano et al., 2013, Eisend \& Schmidt, 2014; Judge et al., 2004, Pfeffer \& Langton, 1993); based on analysis of random factors (Chen et al., 2006; Ramsden, 1994; Smeby \& Try, 2005; Smith et al., 2008); not empirically tested (Creswell, 1985; Fox, 1983); or based on findings of a survey carried out in only one school (Bland et al., 2002; Bland et al., 2005; Wood, 1990).

In sum, there is still a distinct absence of published studies investigating research performance as a complex phenomenon, identifying and empirically testing specific HRM practices enhancing research performance. Moreover, several major questions related to the HRM-individual research performance linkage remain unanswered:
What is research performance? What specific HRM practices stimulate research performance? What are the mediating mechanisms, i.e., what scholarly abilities, attitudes, and behaviors lead to positive research performance?

This paper will overview factors affecting research performance and build a theoretical framework for the HRM-research performance chain. We develop our HRMresearch performance framework based on an HRM-performance chain logic (Becker et al., 1997), including mediating factors (Guest, 1997), on the supposition that a properly designed HRM system yields the skills, abilities, and attitudes required of scholars, leading to their behavior outcomes generating the desired performance outcome (Paauwe \& Boselie, 2005).

Our study contributes to HRM-performance research as follows: First and foremost, grounded in previous studies, we describe research performance and identify specific scholars' skills, abilities, researchoriented attitudes, and behaviors related to research performance and respond to the call for research covering not only proximal (i.e., specific scholars' skills, abilities, research-oriented attitudes, and behaviors) but also distal (research performance measures) HRM outcomes in the HRM-performance chain (Guest, 2011). Second, based on ability, motivation, and opportunity (AMO) theory (Appelbaum et al., 2000) and on theoretical grounding and empirical evidence that individual HRM practices support and reinforce each other and in this way compose HRM bundles generating synergistic effects (Subramony, 2009), we formulate bundles of HRM practices associated with research performance and in so doing expand HRM development in HEIs (since the current HR function "may be less developed in universities than in many 
other sectors"; Guest \& Clinton, 2007, p. 10). Finally, we build a theoretical framework for the HRM-research performance chain, which has not been considered in earlier studies and add to strategic HRM literature by focusing on HRM within HEI.

Our research focuses on the individual research performance level, and we limit the analysis of research performance measures to social sciences to emphasize the specifics of this area since there are considerable variations in research performance and publications between disciplines (Spangenberg et al., 1990).

This paper is based on a literature analysis and is organized as follows. We begin with the theoretical identification of individual research performance measures as the performance outcomes of the HRMperformance chain; then, we determine the mediating factors, i.e., scholars' (as employees) knowledge, skills, and abilities (KSAs) and research-oriented attitudes yielding the requisite behaviors. Finally, based on AMO theory, we outline the bundles of HRM practices enhancing research performance and create a theoretical framework for HRM-research performance linkage.

\section{RESEARCH PERFORMANCE MEASUREMENT IN HIGHER EDUCATION}

To build an HRM-individual research performance chain, we start with an analysis of research performance, seeking to identify industry-specific dependent variables (Boselie et al., 2005) for selecting, creating, and implementing more effectively targeted HR policies (Guest, 1997). Before offering a theoretical analysis, we consider a conceptual discussion concerning the definition of research achievement; in most cases, the terms "research performance" and "research productivity" are used synonymously. This highlights the relevance of discussing the terms "performance" and "productivity" (Boselie et al., 2005; Guest, 1997). We consider the individual achievements of the researcher as research performance, since performance is related to output, whereas productivity is associated with input-output ratios (Guest, 1997) or "output-per-effort exerted" (Boselie et al., 2005, p. 83).

Another ambiguous point concerning the description of the performance is how to interpret performance outcome in the HRM - performance linkage. According to Paauwe and Boselie (2005), several types of HRM performance outcomes can be distinguished: financial (sales, profits, market share, etc.), organizational (productivity, quality, efficiencies, etc.), and HR-related outcomes (employees' satisfaction commitment, intention to quit, and others). Guest (1997) emphasized that these aforementioned outcomes should require consideration in "any model that seeks to understand the impact of the 'human' factor in human resource management" (p. 269). Therefore, we treat research performance as an organizational HR outcome, whereas HR-related outcomes will be discussed in the sections "Research-oriented behaviors" and "Research-oriented attitudes".

Most of the earlier studies lacked a clear definition of research performance measures or described the term mostly in terms of the research output (Creswell, 1985; Fox, 1983). The number of published articles meant the sum of those articles appearing in peer-reviewed journals (Xie \& Shauman, 1998; Horta et al., 2010; Sabharwal \& Hu, 2013; Millar, 2013; Murayama et al., 2015) or the sum of papers published 


\section{Journal of Contemporary Management Issues}

in a specific year/period (Pfeffer \& Langton, 1993; Kiewra \& Creswell, 2000; Teodorescu, 2000; Ding et al., 2010; White et al., 2012), and these have been the most common measures of scientific productivity because of their simplicity (Xie \& Shauman, 1998). Many scholars have used quantity of publications as the only measure of research performance (Fox, 1992; Levitan \& Ray, 1992; Xie \& Shauman, 1998; Ding et al., 2010; White et al., 2012).

However, a simple quantitative measure (number of publications) suffers from several shortcomings. For example, it is not possible to distinguish between articles' impact, their length (Kim et al., 2009), and journal quality (Horta et al., 2010), and so all papers are counted as the same. The use of a quality measure (such as citations, journal impact factors, or another measure) in addition to the number of articles can provide a more complex assessment of productivity (Sabharwal \& Hu, 2013); besides, "a count of publications is a part of most faculty evaluation systems, and a measure of journal quality is often a part of this calculation" (Harris, 2008, p. 374).

Therefore, quality measures, such as journal quality, have been considered as scholars' research performance measure (Judge et al., 2004; Seggie \& Griffith, 2009; Sabharwal \& Hu, 2013; Baker, 2015) and publications in high-level journals can be used as an objective measure reflecting the research productivity, quality, and reputation of scholars (Manning \& Barrette, 2005).

Authors' contribution and co-authorweighted count of publications have been used as another quality-reflecting performance measure (Banal-Estanol et al., 2015).

The number of citations (or citation count) is one of the most disputable research performance measures (Kim et al., 2009; Eisend \& Schmidt, 2014; Murayama et al., 2015). On one hand, citations can serve as the most straightforward measure of an article's impact (Kim et al., 2009); on the other hand, citations accumulate with the age of the article, so measuring productivity by the citation count can lead to very skewed results (Kim et al., 2009). The number of citations may also come under scrutiny owing to factors such as widelyread authors, authoritative journals, popular research topics, and popular fields, all of which can inflate citation totals (Groot \& Garcia-Valderrama, 2006).

To avoid the aforementioned shortcomings, combined research performance measures have been developed. The h-index combines the measures of quantity (publications) and impact (citations) (De Stefano et al., 2013), but it does have some limitations related to different productivity and citation practices in the field, artificial increases in self-citations (Costas \& Bordons, 2007 , p. 194), and a scholar's career span, and does not consider the number of coauthors (Hunter et al., 2009). Smith et al. (2008) operationalized research productivity using a four-step process developing a measure for both quantity and quality, i.e. 1) the number of academic articles, 2) the sum of articles divided by the number of their authors (reflecting the individual contribution of each author), 3) incorporating quality rankings for ascertaining the perceived quality of the article, and, finally, 4) evaluating the time after degree awarded to individuals.

It is worth noting that variations in publications and citations exist among disciplines, so the expressions "high and low performance" should be considered and used in a relative rather than an absolute sense (Spangenberg et al., 1990). 
Books and conference papers have been treated controversially as research performance measures because they tend to be less consistent in nature and quality than papers in peer-reviewed journals (Horta et al., 2010).

We summarize that the quantity of published, peer-reviewed works, number of books and book chapters, authors' contributions, journal quality, and citation counts may be the measures for research performance evaluation in the social science area.

\subsection{Mediating factors in the HRM- research performance linkage}

How HRM might impact performance has undergone intensive investigation in the last couple of decades (Bowen \& Ostroff, 2004; Chuang et al., 2013; Dyer \& Reeves, 1995; Gardner et al., 2001; Wright et al., 1994). Boselie et al. (2005) emphasized a mediating "black box" and its mechanisms to explain how HR practices influence efficiency. A meta-analysis by Jiang et al. (2012) disclosed that different types of HR practices influence performance outcomes through different mediating mechanisms. Therefore, understanding mediating mechanisms in the interplay of HRM and performance is important, since this encompasses the complexities associated with the "black box" (Gardner et al., 2001; Jiang et al., 2013).

An HRM system can serve as a linking mechanism that generates the employees' shared attitudes and behaviors that lead to the desired work outcomes. Strategic HRM emphasizes the development of targeted skills and abilities through the HRM-performance chain, "HRM practices must develop employees' skills, knowledge, and motivation such that employees behave in ways that are instrumental to the implementation of a particular strategy" (Bowen \& Ostroff, 2004, p. 203). Possession of appropriate skills, abilities, and high motivation leads to high performance at the individual level (Guest, 1997). Thus, we have to define the specific attitudes and behaviors leading to research performance.

We consider the HRM-performance mechanism analysis by identifying individual KSAs related to research activities, and then explore the research-oriented attitudes and finally identify the behaviors leading to research performance.

\subsection{KSAs related to research performance}

Individual characteristics are essential for research performance (Creswell, 1985; Fox, 1983; Wood 1990) and have been highlighted as being more important than contextual factors (Smeby \& Try, 2005). Wright et al. (1994) recognize that "although employee behavior is the most direct way in which strategies are implemented, employees must have the competencies, KSAs necessary to exhibit the behaviors" (p. 305). To develop the HRM-research performance linkage, we need to identify specific KSAs necessary for research activities.

Previous studies have revealed specific knowledge that leads to high research performance, educational background, i.e., the institution where a degree was earned (Kiewra \& Creswell, 2000; Smith et al., 2008; Seggie \& Griffith, 2009); academic lineage, i.e., the supervisors, advisors, and scholars who have influenced the researcher's career (Kiewra \& Creswell, 2000); content knowledge, i.e., the familiarity within one's research area with all major published works, different theories, key researchers, 


\section{Journal of Contemporary Management Issues}

and predominant funding sources (Bland et al., 2005); and knowledge accumulated by publishing early in a career with positive feedback (Fox, 1983; Creswell, 1985), thereby establishing productive scholarly work habits (Bland et al., 2005), since later publications can be significantly predicted from the publication number achieved as a Ph.D. student (Judge et al., 2004).

Academic rank, defined as a job title (such as assistant professor, associate professor, full professor; Ramsden, 1994; Hardre et al., 2011; White et al., 2012), correlates strongly with research performance (Hardre et al., 2011). Valle and Schultz (2011) examined faculty records of U.S. business schools, included in the Association to Advance Collegiate Schools of Business's (AACSB) listing of accredited schools, and found that a higher academic rank was linked to higher productivity in top-tier research. Moreover, successful senior faculty members have developed the knowledge and skills necessary to "hone their craft" (Valle \& Schultz, 2011, p. 231), thereby surpassing the junior faculty in research productivity.

Previous research has revealed specific skills and abilities related to research activities, clarity in writing, basic and advanced research skills, "innate" scientific ability or talent for conducting research, and timemanagement skills.

The clarity in writing is understood as writing text arguments clearly and simply (Kiewra \& Creswell, 2000). Basic and advanced research skills are defined as easily forming and applying a study design, data collection and statistical methods, and advanced techniques commonly used in one's area (Bland et al., 2005). "Innate" scientific ability or talent to conduct research (Creswell, 1985) has been described as the distinguishing ability of a productive scholar, although this ability requires empirically tested evidence. Time-management skills have been identified as a key to producing research (White et al., 2012), and internet utilization has also been mentioned as being important for productivity (Ynalvez \& Shrum, 2011).

\subsection{Research-oriented attitudes}

Employee attitudinal outcomes (e.g., extent of employee satisfaction, commitment, motivation, and others) are closely linked to intervening HR policies (Paauwe $\&$ Boselie, 2005), which are intended to enhance certain aspects of behavior.

What are the specific attitudes and motivational drives of researchers? The inner motivation to conduct research has been recognized as one of the main determinants of research performance and the main attitude distinguishing a research-oriented person from others (Fox, 1983; Creswell, 1985). Inner motivation has been defined as an "inner compulsion" (Fox, 1983), a "sacred spark" igniting motivation and desire (Creswell, 1985), the feeling of having a "mission" in life to produce research (Levitan \& Ray, 1992), an internal drive to conduct research (Bland et al., 2002; Bland et al., 2005), and intrinsic academic motivation, for example, "I genuinely enjoy writing for publication" (Ramsden, 1994). All provided terms signal a research-oriented attitude of high devotion to research and attest to the features of a "prolific" scholar, defined by Hunter and Kuh (1984) as "an individual who places little importance on extrinsic sources of motivation, such as salary incentives, and great importance on the genuine enjoyment of engaging in scholarly activities" (as cited in Creswell, 1985, p. 45). Hardre et al. (2011) examined U.S research-based universities' faculty members and found that intrinsic motivation, 
e.g., "I do research because I like to do it", had the strongest correlation with personal research value, research effort, and self-efficacy. Inner motivation to conduct research endures, even in the absence of external rewards (Fox, 1983), and performance appraisal, though important, is insufficient for research enhancement (Pfeffer \& Langton, 1993; Harris, 2008; Herdlein et al., 2008).

The literature review in Fox (1983), based on the determinants of publication productivity, emphasized psychological factors, such as "autonomy" or "self-direction", as being characteristic of the most productive scientists, and Schuelke-Leech (2013) confirmed that the researcher's attitude towards research autonomy "can have a powerful influence on researchers' behavior" (p. 1671). Other attitudes of productive researchers are related to confidence in one's research abilities (Creswell, 1985), academic freedom or autonomy in selecting research topics (Wood, 1990), and commitment to the organization (Bland et al., 2005).

Summing up our analysis, we can consider specific research-oriented attitudes such as inner motivation to conduct research, confidence in one's research abilities, autonomy or self-direction in conducting research, as mediators in the HRM-research performance chain.

\subsection{Research-oriented behaviors}

Previous research has shown that specific behaviors leading to higher research performance are associated with time management, continuous knowledge development, communication, and networking.

Time management is recognized as substantial for productive scholars and involves time allocated to research (Spangenberg et al., 1990; Fox, 1992; Levitan \& Ray, 1992;
Kiewra \& Creswell 2000; Bland et al., 2005; Chen et al., 2006) and consistently working long hours (Levitan \& Ray, 1992). Time set aside for research was highlighted as a crucial input item leading to research output (Smeby \& Try, 2005), and a survey of ten U.S. business schools revealed that time allocation and the ability to devote additional hours to research are the most important variables in conducting research (Chen et al., 2006). Furthermore, faculty members' intense interest in research, their willingness to devote time to research, and their orientation towards research, all support publication productivity (Fox, 1992).

Research knowledge development, by regular reading of scientific journals in a scholar's research area (Levitan \& Ray, 1992), service on editorial boards (Kiewra \& Creswell, 2000; Valle \& Schultz, 2011), professional organizations (Kiewra \& Creswell, 2000), engagement in simultaneous projects (Bland et al., 2005; Fox \& Mohapatra, 2007), have been attributed to research-oriented behavior.

Several other research-oriented behaviors have been related to specific research development activities and defined as "trademark" characteristics (Kiewra \& Creswell, 2000), including collaboration with other researchers or talented students and mentoring of highly productive graduate teams; systematic programming of a research agenda and thus producing research, and undertaking every task in the way that leads ultimately to multiple products, such as teaching, consulting, administration, and others. The availability of doctoral students has been connected to higher productivity in top-tier research since faculty members "without access to doctoral students face an uphill battle to consistently produce toptier publications" (Valle \& Schultz, 2011, p. 231). The stability of research interest 


\section{Journal of Contemporary Management Issues}

in a single domain has been revealed as an important research-oriented attitude as well (Kiewra \& Creswell, 2000).

Finally, communication, collaboration, and networking have been revealed as significant determinants of research performance (Creswell, 1985; Kiewra \& Creswell, 2000; Teodorescu, 2000; Bland et al., 2005; Balconi \& Laboranti, 2006; Ynalvez \& Shrum, 2011; Beaudry \& Allaoui, 2012; Lavie \& Drori, 2012, De Stefano et al., 2013; Seibert et al., 2017). Communication with colleagues from the same institution (Creswell, 1985; Kiewra \& Creswell, 2000; Bland et al., 2005; Lavie $\&$ Drori, 2012) and with scholars in the discipline from other institutions (Creswell, 1985, Levitan \& Ray, 1992; Teodorescu, 2000; Bland et al., 2005) was related to research-oriented work. Collaboration increases the number of citations from conceptual articles when the collaborators are equipped with good English language skills (Eisend \& Schmidt, 2014).

Having a central position in the copublication network (Beaudry \& Allaoui, 2012), or having a central position in the co-authorship networks (De Stefano et al., 2013), had positive effects on research output, and connections with industry were also associated with higher scientific performance (Balconi \& Laboranti, 2006). BanalEstanol et al. (2015) found that the interrelationship of collaboration with industry to publication rates is curvilinear, and the effect of collaboration seems decisive for applied research, whereas fundamental research is positively affected by funding but not related to the extent of collaboration with industry.

According to Fox and Mohapatra (2007), research outcomes are related to "cosmopolitan" collaborative patterns, as networking through international conferences (Teodorescu, 2000) and possession of a well-developed external network (Teodorescu, 2000; Bland et al., 2005) lead to more scholarly contacts and higher research performance. Publication productivity may depend on the national context, but cosmopolitan orientation and membership in professional associations, and attendance at their events are important correlates of research performance (Teodorescu, 2000).

Thus, research-oriented behaviors can be specified as time dedicated to research (allocating time to research and long working hours), involvement in research activities (engagement in research projects, participation in editorial bodies, continuous development of a research agenda (collaboration with talented Ph.D. students, systematic research agenda programming, and undertaking tasks that impact research), stability in the research domain, communication with scholars inside and outside an organization, participation in international conferences, and development of an external network.

\section{HRM PRACTICES ENHANCING SCHOLARS' ABILITIES, MOTIVATION, AND OPPORTUNITIES}

The HRM system is known as a tool that can aid organizations in promoting efficient knowledge behaviors (Chuang et al., 2013). "The goal of HRM is to design and implement HR practices in a way that leads to desired employee attitudes and performance" (Nishii et al., 2008, p. 40), and the value of HRM practices is optimized only when organizations create mechanisms that facilitate the success of employees' contributions (Wright et al., 1994). 
HRM practices generate involvement/ participation systems that allow employees to impart their knowledge, skills, and behaviors (Wright et al., 1999). The proper configuration of HRM practices can help in developing skillful, motivated employees which, as a result of participative mechanisms, can cooperate and produce the desired research output.

An HRM system can typically be composed of different HRM practices, but not all of these may stimulate research activities and knowledge creation (Chuang et al., 2013). Based on Becker et al.'s (1997) model, our developed theoretical framework comprises knowledge, attitudes, skills, abilities, and behavior as mediating factors in the HRM performance chain (Guest, 1997). Employee motivation, skills, job design, and work structures are expected to elicit certain levels of creativity, productivity, and discretionary effort among employees, "which translate into improved operating performance" (Wright et al., 2003, p. 25).

Abilities, motivation, and opportunities are "key mechanisms through which HR systems influence employee performance" (Lepak et al., 2006, p. 230); therefore, organizations have to give employees suitable opportunities to deploy their skills and create work structures enabling employee involvement, participation, and empowerment. Jiang et al. (2012) examined three categories within the HRM system: 1.) skill-, 2.) motivation- and 3.) opportunity-enhancing practices. They found that skill-enhancing HR practices were more positively related to human capital and less positively related to employee motivation than were motivation-enhancing and opportunity-enhancing HR practices. Jiang et al. (2013) analyzed mediating mechanisms in HR-performance linkage and proposed a three-level mediation framework. They identified employee ability, motivation, and opportunity as mediators in the relationship of HR systems with performance outcomes at the individual, team, and organization levels of analysis.

To identify HRM practices constituting the research-enhancing HRM system, we apply the theoretical AMO framework (Appelbaum et al., 2000) and generate three bundles of HRM practices yielding the desired "changes in employees' abilities (A), motivations $(\mathrm{M})$ and opportunities to participate (O)" (Boselie et al. 2005, p. 79). Finally, we create the theoretical HRMresearch performance model as an outcome of our analysis.

\subsection{Research-ability/skill-enhancing HRM practices}

Employees require competency, knowledge, and abilities to achieve expected work outcomes (Wright \& Snell, 1991). Therefore, research ability and skill-enhancing HR practices are intended to provide an organization with appropriately skilled employees (Jiang et al., 2012, p. 1267). Exhaustive recruitment, exacting selection, and extensive, formal, and informal training have been mentioned as the primary ability/skills for building HRM practices (Paauwe \& Boselie, 2005; Jiang et al., 2012). In the case of research activities, the primary objective of ability-enhancing HR practices is to ensure that scholars have, and continuously improve, the KSAs needed to perform the research-oriented work (Chuang et al., 2013). These practices should enable scholars to achieve high quality in their research (Guest, 1997).

The hiring of recent Ph.D. graduates (Smith et al., 2008), academic lineage, meaning the institution where a degree was 


\section{Journal of Contemporary Management Issues}

earned (Kiewra \& Creswell, 2000), and the hiring of alumni of highly-ranked institutions might be predictive of the requisite scholarly knowledge and skills, whereas internal hiring of $\mathrm{Ph} . \mathrm{D}$. graduates is associated with lower productivity (Horta et al., 2010). Therefore, we highlight hiring recent $\mathrm{PhDs}$ and alumni preferably of highly-ranked institutions (Seggie \& Griffith, 2009), preferably with already published papers (Judge et al., 2004), as specific HRM recruitment practices shaping research-oriented skills.

Development of academic writing skills (Kiewra \& Creswell, 2000), improvements in advanced research skills (thereby ensuring familiarity with research methods; Bland et al., 2005), and upgrading internet usage skills (Ynalvez \& Shrum, 2011) can be highlighted as specific HRM training practices that enhance research activities.

As mentioned above, time-management skills and consequently the ability to dedicate sufficient time to research (Creswell, 1985; Spangenberg et al., 1990; Fox, 1992; Levitan \& Ray, 1992; Bland et al., 2002; Bland et al., 2005; Smeby \& Try, 2005; Chen et al., 2006; White et al., 2012) are important determinants of research performance and should be cultivated through adequate development of time-management skills through training.

The research-ability-enhancing HRM bundle consists of recruitment and development practices. Recruitment should be focused on hiring Ph.D. graduates and scholars with research experience and academic writing skills that can be evaluated and evidenced from previous research and published or unpublished papers. A candidate's graduation from an external institution with a recognized research reputation may be a good reference point in the selection process. Training and development practices should ensure that scholars develop the requisite research skills and should include academic writing skills, development, and continuous research-expertise building, updated and upgraded as core HR practices. Improving time management and the ability to use rapidly changing information technologies are important preconditions for effective research processes and high-quality research output.

\subsection{Research-motivation-enhancing HRM practices}

Motivation-enhancing HRM practices are mainly intended to focus scholars' attention on research and involve them in research activities, thereby stimulating and enhancing individuals' motivation (Jiang et al., 2012) and discretionary effort (Chuang et al., 2013).

Managing performance development, comparable and fair compensation, incentives in the form of recognition and financial rewards, substantial benefits, career development and internal promotion opportunities, employment security, and information sharing have been reported as motivation-enhancing HRM practices (Paauwe \& Boselie, 2005; Jiang et al., 2012).

Performance-appraisal systems rewarding high-quality research may increase research quality (Harris, 1990). Therefore, the motivation of academic staff and commitment to research activities could be driven by performance appraisal related to research quality.

Previous studies have considered financial incentives for research and publications as factors related to research productivity (Honeycutt et al., 2010; Pfeffer \& Langton, 1993). Promotion-system satisfaction led to better research performance and viceversa (Ramsden, 1994). Faculty members' 
perception that their departments rewarded research was related to publication productivity (Fox, 1992). However, a greater dispersion of wages within academic departments was linked to lower satisfaction levels among individual faculty members and lower research productivity (Pfeffer \& Langton, 1993).

Based on the arguments above, we can state that research-motivation-enhancing HRM practices involve the customized appraisal of performance, adequate compensation, and career management. More specifically, the HR practices should cover activities such as scholars' performance appraisal related to desired research quality and quantity, fair compensation, and incentives for targeted research outputs. Furthermore, transparent career and promotion systems should increase scholars' motivation.

It is worth noting that extrinsic motivation of productive researchers has been recognized to be less effective than personal autonomy and inner motivation to carry out research (Creswell, 1985), as prolific scholars are less sensitive to extrinsic than to intrinsic motivation (Hunter \& Kuh, 1984; Creswell, 1985). Therefore, as mentioned earlier, appraisal and compensation schemes, though important, are insufficient for improving research performance (Harris, 2008; Herdlein et al., 2008). Hence, support in research-oriented work should increase scholars' motivation and, consequently, research output.

\subsection{Research-opportunity- enhancing HRM practices}

Organizations should give employees opportunities to apply their skills by creating a work structure and the prerequisites for employees' involvement, participation, and empowerment. Research-opportunityenhancing HRM practices are dedicated to establishing suitable conditions for competent and motivated researchers to engage in their work. (Chuang et al., 2013).

Inner motivation to conduct research, as a major component of high research performance can be fostered through adequate job design (Bland et al., 2005; Fox, 1983) and by providing an opportunity for more autonomy and thereby facilitating the research (BFox, 1983; Creswell, 1985; Levitan \& Ray, 1992; Kiewra \& Creswell, 2000; land et al. 2002; Bland et al., 2005). Autonomy in selecting research topics (Wood, 1990) and autonomy in research agenda offer opportunities to enjoy engaging in scholarly activities and support inner motivation to perform research because researchers like to do it (Hardre et al., 2011).

Research funding is one of several institutional tools that enable large studies to be carried out and stimulates scholars' involvement in research. However, in an analysis of motivational factors for faculty to conduct research, funding was not found to be related to real enjoyment of research, and grants did not correlate significantly with research motivation (Chen et al., 2006).

As mentioned above, communication with scholars inside and outside an organization has been identified as significantly influencing research performance, and the availability of innovative information technologies on campus has positively affected scholars' productivity and their collaboration with one another (Ding et al., 2010). Thus, the HRM system which gives researchers opportunities to connect with colleagues can support and facilitate research. HRM practices supporting inside and outside information sharing and encouraging researchers' participation in international 


\section{Journal of Contemporary Management Issues}

scientific events, conferences, and networks should create communication opportunities.

Collaboration with talented students in publishing has been highlighted as another important predictor of high-level research (Kiewra \& Creswell, 2000). Therefore, HRM practices ensuring collaboration with graduate students and Ph.D. students could create an opportunity to increase research productivity.

Research projects and team collaboration have been singled out as important contributors to fruitful research activities (Fox \& Mohapatra, 2007). HRM practices supporting team working and involvement in local and international projects should empower scholars to use their skills.

Therefore, appropriate job design, communication, and collaboration-fostering HR practices providing possibilities to dedicate time to research, autonomy in the research agenda, communication and information sharing, creation of conditions for collaboration with colleagues through international scientific conferences and research networks, supervision of Ph.D. students, involvement in research projects, editorial bodies, and creation of work structures for teamwork on research development could serve as components of the research-opportunity-enhancing HRM group.

Based on researchers' identified competencies, skills, and attitudes as research performance determinants leading to researchoriented behavior, we formulated bundles of HRM practices from requisite abilities, motivation, and opportunities to enhance research performance and build a theoretical HRM-research performance framework (see Figure 1).

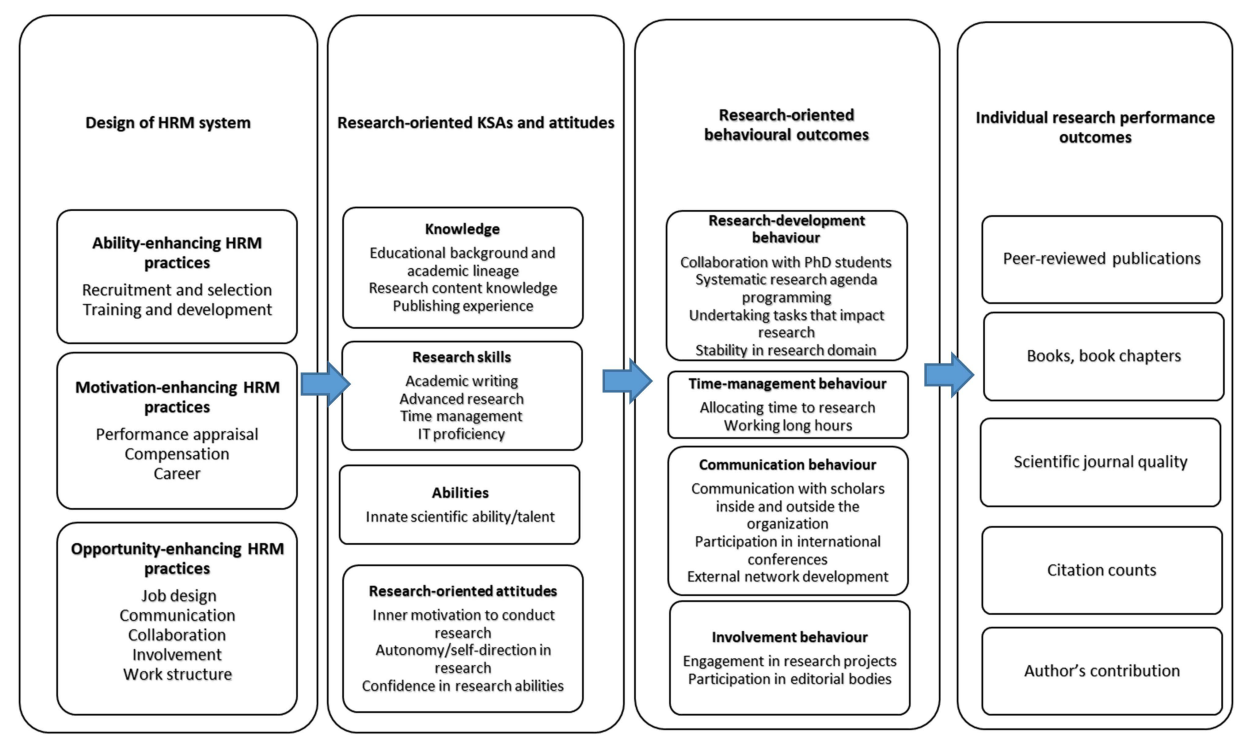

Figure 1. Theoretical framework of the HRM-research performance linkage in higher education institutions 
The logic of the model is that research ability, motivation, and opportunity-enhancing HRM practices foster identified research-oriented KSAs and attitudes, which enhance adequate research-oriented HR outcomes and finally lead to research performance outcomes.

\section{DISCUSSION AND CONCLUSIONS}

Previous studies have suggested the need to widen the contextual boundaries of the HRM-performance linkage, and so this paper has focused on higher education specifics that have been previously under-explored. Our study, to our knowledge, is one of the first theoretical attempts to identify "which models of HRM emerge in which contexts" (Boxall, Huo, Macky, \& Winterton, 2019, p. 4). Based on the literature analysis, we aimed to determine the factors leading to research performance and to build a theoretical HRM-research performance chain, to contribute to the theoretical disclosure of a "black box" in the HRM-research performance linkage, an area that remains under-examined. We identified HRM practices that enhance research-oriented behavior, since earlier studies have signaled the need to foster research performance (Creswell, 1985; Levitan \& Ray, 1992; Kiewra \& Creswell, 2000; Teodorescu, 2000; Bland et al., 2002; Bland et al., 2005; Smeby \& Try, 2005; Fox \& Mohapatra, 2007; Smith et al., 2008; White et al., 2012). Since a positive influence of the HRM system is stronger than that of individual HRM practices (Combs et al., 2006), we considered the HRM system as a set of bundles of HR practices acting in unison to create a work environment supporting the development of high-quality research to be published. We discussed the research performance measures, identified scholars' knowledge, skills, abilities, research-oriented attitudes, and behaviors, and consequently defined the specific groups of HRM practices related to research performance enhancement. Finally, we propose a theoretical model of the HRM-research performance chain.

Our model provides theoretical explanations of mediating factors in HRM-research performance linkage and response to Buller and McEvoy's (2012) call, by displaying HRM practices customized for research institutions that are "essential organizational mechanisms for generating, reinforcing, and sustaining employee actions in line with organizational capabilities/culture, group-level job competencies/norms, and individual KSAs/motivation/opportunity" (p. 52). Our theoretical HRM-research performance framework can be a point of reference for HRM practitioners in higher education and research institutions to enhance research performance and shed light on HRM development in this context.

\section{LIMITATIONS AND DIRECTIONS FOR FUTURE STUDIES}

This paper has some important limitations which require consideration in subsequent studies. First, our study endeavors to develop a theoretical HRM-performance model for research-output generation and complies with a deductive approach in the theory-building process (Christensen \& Carlile, 2009). We recognize that the set of scholars' KSAs, attitudes, and behaviors associated with research performance is derived from a small number of previous studies based on frugal empirical evidence. Therefore, the next step in the development of HRM-research performance theoretical linkage should be a qualitative exploration 


\section{Journal of Contemporary Management Issues}

of other mediators in HRM-research performance linkage.

Second, we have limited the research performance measures to the social sciences, so future research should perhaps focus on re-examining the HRM-performance model in other research settings. Third, the role of line managers and departments in enhancing research performance should be kept in mind, since they are major actors in HRM implementation (Kuvaas, 2008; Boxall et al., 2011). Fourth, our proposed model should be tested empirically using multisource data, considering intended and implemented HRM practices, as well as combining and examining different levels (individual, departmental, organizational, institutional, and national) of analysis and multi-level investigations (Guest, 2011). Finally, the internal consistency of HRM bundles should be evaluated (MacDuffie, 1995; Delery \& Doty, 1996), which could be challenging, as the importance of HRM practices in HRM bundles could differ depending on an organization's HR strategy (e.g., recruitment of already highly performing scholars or intensive internal development of fresh Ph.D. graduates). Likewise, we limited our study to the components of HRM bundles but did not consider the description of HRM processes and techniques, such as recruitment, performance appraisal, or other processes.

There is no "one best way" of applying diverse HR practices (Mayrhofer et al. 2004), though our framework proposes the starting point of the specific HR configuration and mediating mechanisms that should be taken into consideration in applying HRM to enhance research performance in HEIs.

\section{REFERENCES}

1. Appelbaum, E., Bailey, T., Berg, P., \& Kalleberg, A. (2000). Manufacturing Advantage: Why High-Performance Work Systems Pay Off. Ithaca, NY, Cornell University Press.

2. Baker, A. (2015). Non-tenured postdoctoral researchers' job mobility and research output: An analysis of the role of research discipline, department size, and coauthors. Research Policy, 44(3), 634-650.

3. Balconi, M., \& Laboranti, A. (2006). University-industry interactions in applied research: The case of microelectronics. Research Policy, 35(10), 1616-1630.

4. Banal-Estanol, A., Jofre-Bonet, M., \& Lawson, C. (2015). The doubleedged sword of industry collaboration: Evidence from engineering academics in the UK. Research Policy, 44(6), 1160-1175.

5. Baruffaldi, S. H., \& Landoni, P. (2012). Return mobility and scientific productivity of researchers working abroad: The role of home country linkages. Research Policy, 41(9), 1655-1665.

6. Beaudry, C., \& Allaoui, S. (2012). Impact of public and private research funding on scientific production: The case of nanotechnology. Research Policy, 41(9), 1589-1606.

7. Becker, B. E., Huselid, M. A., Pickus, P. S., \& Spratt, M. F. (1997). HR as a source of shareholder value: Research and recommendations. Human Resource Management, 36(1), 39-47.

8. Beerkens, M. (2013). Facts and fads in academic research management: The effect of management practices 
Management, Vol. 26, 2021, No. 1, pp. 149-168 J. Jaškienė, I. Buciuniene: HUMAN RESOURCE MANAGEMENT-RESEARCH ...

on research productivity in Australia. Research Policy, 42(9), 1679-1693.

9. Bland, C.J., Center, B. A., Finstad, D.A., Risbey K.R., \& Staples, J.G. (2005). A theoretical, practical, predictive model of faculty and department research productivity. Academic Medicine, 80(3), 225-237.

10. Bland, C.J., Seaquist, E., Pacala, J.T., Center, B. A., \& Finstad, D.A. (2002). One school's strategy to assess and improve the vitality of its faculty. Academic Medicine, 77(5), 368-376.

11. Boselie, P., Dietz, G., \& Boon, C. (2005). Commonalities and contradictions in HRM and performance research. Human Resource Management Journal, 15(3), 67-94.

12. Boxall, P., Ang, S. H. \& Bartram, T. (2011). Analysing the "black box" of HRM, uncovering HR goals, mediators, and outcomes in a standardized service environment. Journal of Management Studies, 48, 1504-32.

13. Boxall, P., Huo, M. L., Macky, K., \& Winterton, J. (2019). High involvement work processes and systems, a review of theory, distribution, outcomes, and tensions. In Research in Personnel and Human Resources Management (pp. 1-52). Emerald Group Publishing Ltd.

14. Boxall, P., \& Steeneveld, M. (1999). Human resource strategy and competitive advantage: A longitudinal study of engineering consultancies. Journal of Management studies, 36(4), 443-463.

15. Bowen, D. E., \& Ostroff, C. (2004). Understanding HRM-firm performance linkages: The role of the "strength" of the HRM system. Academy of Management Review, 29(2), 203-221.

16. Buller, P. F., \& McEvoy, G. M. (2012). Strategy, human resource management and performance: Sharpening line of sight. Human Resource Management Review, 22(1), 43-56.

17. Chen, Y., Gupta, A., \& Hoshower, L. (2006). Factors that motivate business faculty to conduct research: An expectancy theory analysis. Journal of Education for Business, 81(4), 179-189.

18. Christensen, C. M., \& Carlile, P. R. (2009). Course research: Using the case method to build and teach management theory. Academy of Management Learning \& Education, $8(2), 240-251$.

19. Chuang, C. H., Jackson, S. E., \& Jiang, Y. (2016). Can knowledge-intensive teamwork be managed? Examining the roles of HRM systems, leadership, and tacit knowledge. Journal of Management, 42(2), 524-554.

20. Combs, J., Liu, Y., Hall, A., \& Ketchen, D. (2006). How much do high-performance work practices matter? A meta-analysis of their effects on organizational performance. Personnel Psychology, 59, 501-528.

21. Costas, R., \& Bordons, M. (2007). The h-index: Advantages, limitations and its relation with other bibliometric indicators at the micro level. Journal of Informetrics, 1(3), 193-203.

22. Creswell, J. W. (1985). Faculty research performance: Lessons from the sciences and the social sciences. Association for the Study of Higher Education \& ERIC Clearinghouse on, Higher Education, ASHE-ERIC higher education report No. 4.

23. Datta, D. K., Guthrie, J. P., \& Wright, P. M. (2005). Human resource management and labor productivity: Does industry matter?. Academy of Management Journal, 48(1), 135-145. 


\section{Journal of Contemporary Management Issues}

24. De Stefano, D., Fuccella, V., Vitale, M. P., \& Zaccarin, S. (2013). The use of different data sources in the analysis of co-authorship networks and scientific performance. Social Networks, 35(3), 370-381.

25. Delery, J. E. (1998). Issues of fit in strategic human resource management: Implications for research. Human Resource Management Review, 8(3), 289-309.

26. Delery, J. E., \& Doty, D. H. (1996). Modes of theorizing in strategic human resource management: Tests of universalistic, contingency, and configurational performance predictions. Academy of Management Journal, 39(4), 802-835.

27. Ding, W. W., Levin, S. G., Stephan, P. E., \& Winkler, A. E. (2010). The impact of information technology on academic scientists' productivity and collaboration patterns. Management Science, 56(9), 1439-1461.

28. Dyer, L., \& Reeves, T. (1995). Human resource strategies and firm performance: What do we know and where do we need to go?. International Journal of Human Resource Management, 6(3), 656-670.

29. Eisend, M., \& Schmidt, S. (2014). The influence of knowledge-based resources and business scholars' internationalization strategies on research performance. Research Policy, 43(1), 48-59.

30. Fox, M. F. (1983). Publication Productivity among Scientists: A Critical Review. Social Studies of Science, 13(2), 285-305.

31. Fox, M. F. (1992). Research, Teaching, and Publication Productivity Mutuality Versus Competition in Academia. Sociology of Education, 65(4), 293-305.
32. Fox, M. F., \& Mohapatra, S. (2007) Social-organizational characteristics of work and publication productivity among academic scientists in doctoral-granting departments. Journal of Higher Education, 78(5), 543-571.

33. Gardner, T. M., Moynihan, L. M., Park, H. J., \& Wright, P. M. (2001). Beginning to unlock the black box in the HR firm performance relationship: The impact of HR practices on employee attitudes and employee outcomes. CAHRS Working Paper Series, 75.

34. Groot, T., \& Garcia-Valderrama, T. (2006). Research quality and efficiency - An analysis of assessments and management issues in Dutch economics and business research programs. Research Policy, 35(9), 1362-1376.

35. Guest, D. E. (1997). Human resource management and performance, a review and research agenda. International Journal of Human Resource Management, 8(3), 263-276.

36. Guest, D. E. (2011). Human resource management and performance, still searching for some answers. Human Resource Management Journal, 21(1), 3-13.

37. Guest, D.E. \& Clinton, M. (2007). Human resource management and university performance, final report. Leadership Foundation for Higher Education. Research and Development series.

38. Hardre, P. L., Beesley, A. D., Miller, R. L., \& Pace, T. M. (2011). Faculty motivation to do research: Across disciplines in research-extensive universities. Journal of the Professoriate, 5(1), 35-69.

39. Harris, C. (2008). Ranking the Management Journals. Journal of Scholarly Publishing, 39(4), 373-409. 
Management, Vol. 26, 2021, No. 1, pp. 149-168 J. Jaškienė, I. Buciuniene: HUMAN RESOURCE MANAGEMENT-RESEARCH ...

40. Harris, G. T. (1990). Research output in Australian university economics departments: An update for 1984-88. Australian Economic Papers, 29(55), 249-259.

41. Herdlein, R., Kukemelk, H., \& Türk, K. (2008). A survey of academic officers regarding performance appraisal in Estonian and American universities. Journal of Higher Education Policy and Management, 30(4), 387-399.

42. Honeycutt, E.D., Thelen, Sh.T., \& Ford, J.B. (2010). Evaluating and Motivating Faculty Performance: Challenges for Marketing Chairs. Marketing Education Review, 20(3), 203-214.

43. Horta, H., Veloso, F. M., \& Grediaga, R. (2010). Navel gazing, academic inbreeding and scientific productivity. Management Science, 56(3), 414-429.

44. Hunter, D. E., \& Kuh, G. D. (1984). A Profile of Prolific Scholars in Higher Education. In annual meeting of the American Educational Research Association, New Orleans.

45. Hunter, R. S., Oswald, A. J., and Charlton, B. G. (2009). The Elite Brain Drain. The Economic Journal, 119(538), F231-F251.

46. Jiang, K. F., Lepak, D. P., Hu, J., \& Baer, J. C. (2012.) How does human resource management influence organizational outcomes? A meta-analytic investigation of mediating mechanisms. Academy of Management Journal, 55(6), 1264-1294.

47. Jiang, K. F., Takeuchi, R., \& Lepak, D. P. (2013). Where do we go from here? New perspectives on the black box in strategic human resource management research. Journal of Management Studies, 50(8), 1448-1480.
48. Judge, T. A., Kammeyer-Mueller, J., \& Bretz, R. D. (2004). A longitudinal model of sponsorship and career success: A study of industrial-organizational psychologists. Personnel Psychology, 57(2), 271-303.

49. Kiewra, K. A., \& Creswell, J. W. (2000). Conversations with three highly productive educational psychologists: Richard Anderson, Richard Mayer, and Michael Pressley. Educational Psychology Review, 12(1), 135-161.

50. Kim, E. H., Morse, A., \& Zingales, L. (2009). Are elite universities losing their competitive edge?. Journal of Financial Economics, 93(3), 353-381.

51. Kuvaas, B. (2008). An exploration of how the employee-organization relationship affects the linkage between perception of developmental human resource practices and employee outcomes. Journal of Management Studies, 45(1), 1-25.

52. Lavie, D., \& Drori, I. (2012). Collaborating for Knowledge Creation and Application: The Case of Nanotechnology Research Programs. Organization Science, 23(3), 704-724.

53. Lepak, D. P., Liao, H., Chung, Y., \& Harden, E. E. (2006). A conceptual review of human resource management systems in strategic human resource management research. Research in Personnel and Human Resources Management, 25(1), 217-271.

54. Levitan, A. S., \& Ray, R. (1992). Personal and institutional characteristics affecting research productivity of academic accountants. Journal of Education for Business, 67(6), 335-341.

55. MacDuffie, J. P. (1995). Human resource bundles and manufacturing 


\section{Journal of Contemporary Management Issues}

performance: Organizational logic and flexible production systems in the world auto industry. Industrial \& Labor Relations Review, 48(2), 197-221.

56. Manning, L. M., \& Barrette, J. (2005). Research performance management in academe. Canadian Journal of Administrative Sciences, 22(4), 273-287.

57. Mayrhofer, W., Müller-Camen, M., Ledolter, J., Strunk, G., \& Erten, C. (2004). Devolving responsibilities for human resources to line management? An empirical study about convergence in Europe. Journal for East European Management Studies, 123-146.

58. Millar, M. M. (2013). Interdisciplinary research and the early career: The effect of interdisciplinary dissertation research on career placement and publication productivity of doctoral graduates in the sciences. Research Policy, 42(5), 1152-1164.

59. Murayama, K., Nirei, M., \& Shimizu, H. (2015). Management of science, serendipity, and research performance: Evidence from a survey of scientists in Japan and the US. Research Policy, 44(4), 862-873.

60. Nishii, L. H., Lepak, D. P., \& Schneider, B. (2008). Employee attributions of the "why" of HR practices: Their effects on employee attitudes and behaviors, and customer satisfaction. Personnel Psychology, 61(3), 503-545.

61. Paauwe, J., \& Boselie, P. (2005). HRM and performance: What next?. Human Resource Management Journal, 15(4), 68-83.

62. Pfeffer, J., \& Langton, N. (1993). The effect of wage dispersion on satisfaction, productivity, and working collaboratively - evidence from college and university-faculty. Administrative Science Quarterly, 38(3), 382-407.

63. Ramsden, P. (1994). Describing and explaining research productivity. Higher Education, 28(2), 207-226.

64. Rodriguez-Navarro, A., \& Narin, F. (2018). European Paradox or DelusionAre European Science and Economy Outdated?. Science and Public Policy, 45, 1, 14-23.

65. Sabharwal, M., \& Hu, Q. (2013). Participation in university-based research centers: Is it helping or hurting researchers?. Research Policy, 42(6-7), 1301-1311.

66. Schuelke-Leech, B.-A. (2013). Resources and research: An empirical study of the influence of departmental research resources on individual STEM researchers involvement with industry. Research Policy, 42(9), 1667-1678.

67. Seggie, S. H., \& Griffith, D. A. (2009). What does it take to get promoted in marketing academia? Understanding exceptional publication productivity in the leading marketing journals. Journal of Marketing, 73(1), 122-132.

68. Seibert, S. E., Kacmar, K. M., Kraimer Downes, P. E., \& Noble, D. (2017). The role of research strategies and professional networks in management scholars' productivity. Journal of Management, 43, 4, 1103-1130.

69. Smeby, J., \& Try, S. (2005). Departmental contexts and faculty research activity in Norway. Research in Higher Education, 46(6), 593-619.

70. Smith, J. S., Fox, G. L., Sung-Hee "Sunny" Park, \& Lee, L. (2008). Institutional antecedents to research productivity in operations: The US perspective. International Journal of Operations \& Production Management, 28(1), 7-26. 
Management, Vol. 26, 2021, No. 1, pp. 149-168 J. Jaškienè, I. Buciuniene: HUMAN RESOURCE MANAGEMENT-RESEARCH ...

71. Spangenberg, J. F. A., Starmans, R., Bally, Y. W., Breemhaar, B., Nijhuis, F. J. N., \& Vandorp, C. A. F. (1990). Prediction of scientific performance in clinical medicine. Research Policy, 19(3), 239-255.

72. Subramony, M. (2009). A meta-analytic investigation of the relationship between HRM bundles and firm performance. Human resource management, 48(5), 745-768.

73. Teodorescu, D. (2000). Correlates of faculty publication productivity: A cross-national analysis. Higher Education, 39(2), 201-222.

74. Valle, M., \& Schultz, K. (2011). The etiology of top-tier publications in management: A status attainment perspective on academic career success. Career Development International, 16(3), 220-237.

75. White, C. S., James, K., Burke, L. A., \& Allen, R. S. (2012). What makes a "research star"? Factors influencing the research productivity of business faculty. International Journal of Productivity and Performance Management, 61(6), 584-602.

76. Wood, F. (1990). Factors influencing research performance of university academic staff. Higher Education, 19(1), 81-100.

77. Wright, P. M., \& Snell, S. A. (1991). Toward an integrative view of strategic human resource management. Human Resource Management Review, 1(3), 203-225.

78. Wright, P. M., McCormick, B., Sherman, W. S., \& McMahan, G. C. (1999). The role of human resource practices in petro-chemical refinery performance. International Journal of Human Resource Management, 10(4), 551-571.

79. Wright, P. M., McMahan, G. C., \& McWilliams, A. (1994). Human resources and sustained competitive advantage: A resource-based perspective. International Journal of Human Resource Management, 5(2), 301-326.

80. Wright, P.M., Gardner, T.M. \& Moynihan, L.M. (2003). The impact of HR practices on the performance of business units. Human Resource Management Journal, 13(3), 21-36.

81. Xie, Y., \& Shauman, K. A. (1998). Sex differences in research productivity: New evidence about an old puzzle. American Sociological Review, 63(6), 847-870.

82. Ynalvez, M. A., \& Shrum, W. M. (2011). Professional networks, scientific collaboration, and publication productivity in resource-constrained research institutions in a developing country. Research Policy, 40(2), 204-216. 


\title{
POVEZANOST UPRAVLJANJA LJUDSKIM \\ POTENCIJALIMA I ISTRAŽIVAČKIH REZULTATA U \\ INSTITUCIJAMA VISOKOG OBRAZOVANJA
}

\begin{abstract}
Sažetak
Unapređenje istraživačkih rezultata je dobilo na značaju u posljednjih nekoliko desetljeća. Međutim, broj studija, u kojima se analiziraju odrednice istraživačkih rezultata te pokušavaju identificirati prakse upravljanja ljudskim potencijalima (ULJP), koje unapređuju navedene rezultate, vrlo je mali te su međusobno nekonzistentne. Cilj je ovog rada analizirati utjecajne čimbenike, značajne za istraživačke rezultate te odgovoriti na pozive za praksama ULJP, prilagođenim istraživačkim i institucijama visokog obrazovanja. Rad se temelji na teorijskim vezama izmedu ULJP-a

i organizacijskih rezultata te teži identificiranju mjera istraživačkih rezultata; definiranju vještina, sposobnosti i stavova, kao i ponašanja, relevantnih za ostvarivanje istraživačkih rezultata; i na kraju, utvrđivanju skupina sposobnosti, motivacije i mogućnosti za unapređenje praksi ULJP-a, povezanih s istraživačkim rezultatima. Na kraju se razvija teorijski okvir, koji povezuje ULJP s istraživačkim rezultatima.

Ključne riječi: prakse ULJP, veza između ULJP $i$ rezultata, istraživački rezultati, institucije visokog obrazovanja
\end{abstract}

